\title{
Child abuse, a case report
}

\author{
Andri M.T. Lubis, Syaiful A Hadi
}

\begin{abstract}
Abstrak
Penganiayaan anak merupakan masalah sosial dan masalah medis yang penting dan dapat menyebabkan kecacatan dan kematian pada anak. Angka kejadian penganiayaan anak dalam setahun diperkirakan sekitar 15 sampai 42 kasus diantara 1000 anak dan terdapat kecenderungan peningkatan. Patah tulang merupakan tanda klinis kedua terbanyak yang ditemukan setelah lesi kulit, dan sekitar sepertiga anak yang teraniaya akan mendatangi ahli bedah tulang. Kami melaporkan seorang anak laki-laki berusia 7 bulan yang diduga mengalami penganiyaan anak. Diagnosis kami didasarkan pada temuan patah tulang multiple, keterlambatan dalam mencari pertolongan medis dan perbedaan antara riwayat perjalanan penyakit dengan temuan klinis. Anak tersebut mengalami patah tulang multipel dengan proses penyembuhan yang bervariasi, termasuk patah tulang pada suprakondilar humerus kiri, radius dan ulna kiri, radius dan ulna kanan, kedua tulang femur, tibia kanan serta tibia dan fibula kiri. Pemeriksaan radiologis merupakan modalitas yang penting dalam menegakkan kemungkinan adanya penganiayaan pada anak tersebut. Anak tersebut telah mendapatkan penanganan medis, proteksi, kelompok konsultasi untuk kedua orang tua dan sedang dalam penyelidikan pihak kepolisian. (Med J Indones 2004; 13: 59-65)
\end{abstract}

\begin{abstract}
Child abuse is a pervasive social and medical problem that remains a major cause of disability and death among children. The annual incidence of abuse is estimated to be 15 to 42 cases per 1,000 children and appears to be increasing. Fractures are the second most common presentation of physical abuse after skin lesions, and approximately one third of abused children will eventually be seen by an orthopedic surgeon. We report a 7-month-old boy who was suspected to be abused. Our diagnosis was based on findings of multiple fractures, delay in seeking medical treatment and discrepancy between the history of illness and the clinical findings. He sustained multiple fractures in variety of healing, namely fractures on left supracondylar humeri, left radius and ulna, right radius and ulna, both femora, right tibia, and left tibia and fibula. Radiological examination was an important modality in revealing the possibility of abuse on this child. He had received medical treatment, protection, consultation team for the parents and an underway police investigation. (Med J Indones 2004; 13: 59-65)
\end{abstract}

Keywords: child, abuse

Child abuse or known as the battered child syndrome is a clinical condition imposed on children that are

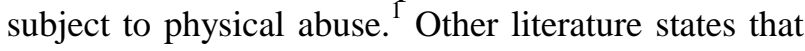
physically abused child is a term coined to define a clinical condition identified in children who are exposed to violence or injury as the consequence of some accidents in one or some incidences performed by the parents, surrogate or the nursing people. ${ }^{2-6}$ The number of new physical abuse cases recorded at Integrated Crisis Center of Cipto Mangunkusumo Hospital from June 2000 until June 2001 was 13 cases. In the United States, it is estimated that

Department of Surgery, Orthopedic and Traumatology Division, Faculty of Medicine, University of Indonesia / Dr. Cipto Mangunkusumo Hospital, Jakarta, Indonesia
1,500,000 child abuse cases occur annually. Out of them, approximately 380.000 cases are identified as physical abuse. ${ }^{5}$ Other literature reports that 15 up to 42 cases in 1000 children are child abuse cases. ${ }^{7}$

The management of child abuse cases includes cooperation with a multidisciplinary team, encompassing orthopedic surgeons.

\section{CASE}

A 7-month old boy was referred by a general practitioner at one private hospital with the history of multiple fractures. The patient was hospitalized at the Department of Orthopedic Surgery of Dr. Cipto Mangunkusumo Hospital. The patient had the history of falling off the swing from a height of 0.5 meter one 
week prior to admission to a private hospital presented to the emergency unit, accompanied by his aunt and house-maid. The patient did not pass out and it was said that he could still do his activities as usual. When the incidence occurred, he was in the hands of his baby-sitter while his mother was out of town. Two days prior to admission to a private hospital, the patient developed fever, swollen right leg and swollen left arm and leg. The patient was hospitalized due to his skin traction at the private hospital and then upon the family's request, patient was referred to our Department.

On physical examination, the patient was alert with 68 centimeters of body length and 42.5 centimeters of head circumference. Paresis of cranial nerve was not found and the general status was within the normal limits. There were brownish spots on the chest, abdomen and neck with the measurements of $2 \times 3 \mathrm{~cm}$, $3 \times 4 \mathrm{~cm}$ and $2 \times 4 \mathrm{~cm}$. Macula erithematous, roughness and squama was found.

On the humerus and left antebrachii region, elastic bandage was put on. There were deformities, and pain to the touch and altered function. In the regions of right and left lower legs there were a skin traction, deformity, pain to the touch and altered function.

Laboratory examination revealed hemoglobin level of $10.3 \mathrm{~g} / \mathrm{dl}$, WBC $12,300 / \mu \mathrm{l}$, platelets $31,000 / \mu \mathrm{l}$, alkaline phosphatase $108 / \mu \mathrm{l}$, calcium $9.4 \mathrm{mg} / \mathrm{dl}$, magnesium $2 \mathrm{mg} / \mathrm{dl}$, phospate $4.5 \mathrm{ml} / \mathrm{dl}$. Urinalysis showed normal results.

Bone survey examination revealed that there was no indication of fractures at the anteroposterior (AP) cranium / lateral and there was no impression of wormian bones. Upper extremity study revealed greenstick fracture at the left humerus, supracondylus bone. A fracture (with the callus formation) with the deformity of angulation was visible at the medical radius bone and left ulna. A fracture was also found at the medical radius bone and left ulna. Furthermore, fracture with callus formation and with a little deformity of angulation was visible at the medical radius bone and right ulna. No fracture or dislocation was found on pelvic joints.

Lower extremity $\mathrm{x}$-ray studies showed a fracture on the distal right femur with formation of at the tip of the fractured fragment. The fracture was on the right tibia. Other fracture was found on distal tibia and right fibula with the callus formation. A fracture was found on the left distal femur (with dislocation of the proximal to the medial) with the callus formation at the tip of the fractured fragment. Greenstick fractures on the proximal left tibia, distal tibia fracture and left fibula with callus formation were also identified. Consultation to the Dermatology and Venereology revealed the presence of erosive dermatitis and it was recommended that hydrocortisone be applied. The definite diagnose were multiple fractures, erosive dermatitis, and child abuse. The management involved placement of Bryant traction and cast and administration of hydrocortisone cream and multivitamins.

The medical record was completely set up and recorded important data such as bone survey. The family members were given guideline for child nursing, right child discipline training, convention socialization on children's rights. Investigation by a multidisciplinary team and police officers was performed. The current results revealed suspicion of child abuse. However, up to now, this case has not been able to be proven and brought to court due to the fact that the witnesses (baby sitter and housemaid) left without any notification and without the known address. Meanwhile, the patient's mother had moved to other city (Solo).

\section{Home visit in Solo}

When the patient was 2 years and six months old, his body weight was $11.8 \mathrm{~kg}$, body height $88 \mathrm{~cm}$ and headline was $47.5 \mathrm{~cm}$. The patient was under the care of his mother and grandparents. There was no history of falling, injury or hospitalization. Since moving to Solo, the patient had never had any follow-up visit for his fractures. So far, the patient's family had still been under the impression that the guilty ones were the baby-sitter and the housemaid.

On physical examination the child was found alert with good vital signs. The general status revealed neither hematoma nor edema. On walking, there was no impression of limp, being able to do activities as usual and the right leg was rather bent. During observation, the patient looked happy, playing with his siblings and peers. There was no impression of depression or fright toward the family members as well as other people. The patient's mother and his siblings as well as the other family members appeared to love the patient. On radiological examination, new bone fractures were not found and the previous bone fractures had healed, with the impression of bent right femur. 


\section{DISCUSSION}

Child abuse is adults' conduct or older children's conduct by exerting the power or authority on helpless children who should actually be under their responsibility or nursing which is potential to cause sufferings, misery, and even disability. ${ }^{1-8}$

Concern with child cause has so far been divided into four periods; the first period occurring prior to 1946 in which child abuse was not known yet, the second period taking place from 1946 - 1962 in which the image of child abuse had started to come to the surface but was not yet referred to as child abuse. The third period between 1962 and 1974 was the first time that the term child abuse was known but it was more familiar with the term "the battered baby syndrome". Since 1974 to date, it has been the fourth period in which protective, curative measures as well as bigger attention to sexual abuse have been augmented. The fifth period is expected to be reached, namely the period that emphasizes on preventive measures. ${ }^{9}$

Some countries have made legal regulations that corporal punishment is an illegal action. The most important points of the regulations are effective education, parental training on nursing patterns and use of other discipline methods that are more effective than corporal punishment. Combination of reward conferring, positive motivation and nonphysical punishment will prevent wrong child conduct. The incidence of child abuse in the next generation has been reduced since corporal punishment was not anymore used as a reaction to wrong conduct in children. $^{10}$

The major characteristic of physical abuse is disaccord between the history and the present trauma. ${ }^{1-7,11}$ The transient diagnosis was established based on the findings of injury which are not in accordance with the cause of the reported injury. The presence of hematoma, burn and scars in children under 3 years of age is a quite pathognomonic finding.

On the imaging examination, metaphyses fractures or multiple fractures are found at every stage of bone healing. This condition uncovered repeated violence and bore a diagnostic value.$^{6-8}$ Children falling off a bed will not cause any fracture. ${ }^{6,712}$ In our case, the suspected diagnosis of child abuse was based on the disaccord between the history of falling from a height of 0.5 meter and the occurrence of numerous fractures. On radiological findings, fractures were found with a variety of different healing phases. Quite long time had elapsed between the moment it happened and the beginning of the treatment caused by the lack of attention of the parent and baby-sitter.

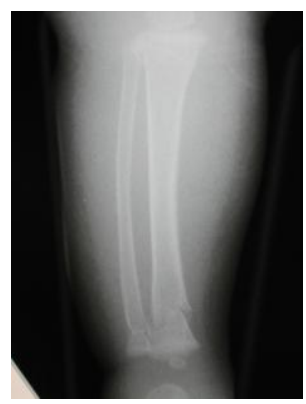

Figure 1.

Metaphyseal fracture at distal and proximal tibia

The incidence of physical abuse in USA in 1993 was $5.7 / 1000$ children. The rate of the incidence was 33\% of increase to the incidences in 1986 which was 4.3/1000 children. The following various clinical appearances are as follows: bone fractures $30 \%$, burn cases $9-10 \%$, hematoma $40 \%$, and head trauma $24 \%$. The incidence of disability caused by physical abuse is 147 / 1000 child abuse cases. It is estimated that 1500 child die annually with the mortality $0.02 / 1000$ children. ${ }^{5}$ Since the establishment of Integrated Crisis Center at Cipto Mangunkusumo Hospital from June 2000 until June 2001, 13 physical abuse cases had been recorded with 1 case ended up with death.

This rate looked insignificant because of the lack of socialization and suspicion toward those cases. There is no significant difference in the incidence rate regarding nationality. Physical abuse occurs to boys as well as girls with the ratio $5.8 / 1000$ boys and $5.6 / 1000$ girls. The risk of more serious injury is higher in boys, and the incidence of physical abuse occurs most to children ranging 5-6 years of age followed with those of $12-14$ years of age and the lowest incidence lies in children under 2 years old. ${ }^{5-7}$

Physical abuse generally occurs due to the presence of stress in the family. The sources of stress are divided into: (1) child produced stress as found in families with mentally retarded, misconduct, or disabled children; (2) social - situational stress, such as idle parents, numerous children, or unexpected children; (3) parent - produced stress, such as depressed parents or those with psychiatric disorders, relationships lacking harmony or mistreated parent, in the past. ${ }^{8}$ 
In our case, had the abuser been the parents, the possibility of the stress source could have been derived from social-situational stress, parent produced stress and triggering situations.

The triggering and contributive factors may $b^{2}(1)$ parents' factor; (2) family situation factor; (3) child factor; (4) cultural factor.

The causes of child abuse are usually multiple and are usually correlated with several factors. ${ }^{5}$ In our case, the source of stress is expected to derive from a variety of sources regarding the difficulty at that time in the patient's parents' business and the possibility of the love affairs driving the mother not to be able to respond well to the every day situation resulting in ignorance of pregnancy up to the twelve weeks' period raising the probability that the pregnancy was not expected at all. The other cause which can not be eliminated is the involvement of the baby sitter and the house-maid. They were irritable and rough on children and when the patient was hospitalized; those two people disappeared without any notification and did not leave any address. The child's tendency to be troublesome is expected to be the triggering factor for the physical abuse in our case.

Attention and thorough examination are required if the following clues are spotted, especially if found in some uncommon areas of the body.

1. Hematoma and scratches on the face, lips/mouth or in the other areas of the body. They could be fresh hematoma or scratches or the healing ones. The patterns of the hematoma or scratches could uncover the object used to do the violence. ${ }^{2,6,7}$

2. Abrasions and lacerations on the mouth, lips, eyes, ears, arms, hands, genitals, bite injury. In the other areas of the body, fresh injury or the repeated injury could be found., ${ }^{2,6,7}$

3. Fractures. Every bone fracture that occurs to children under 3 years of age, especially if multiple, ${ }^{6,7,11-15}$ should be carefully examined for possible abuse. Fresh bone fractures or the healing ones which could be found at the same time.

4. Burn injury, on the hands, legs or buttocks because of contact with scorching object such as cigarette. Typical injury patterns that are commensurate with the shapes of scorching objects used to imprint such injury.

5. Head injury. Subcutaneous hematoma and / or subdural which can be depicted by x-rays. Bald areas that are caused by hair removement.

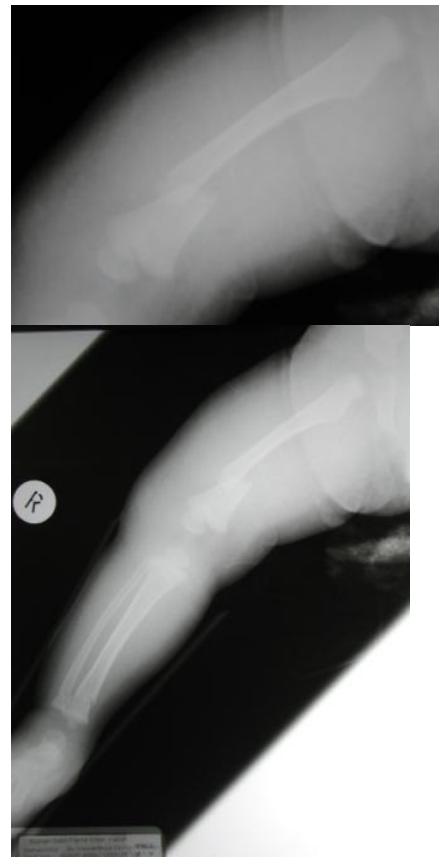

Figure 2 .

Multipel fractures on the right femur, right tibia and fibula, right antebrachii

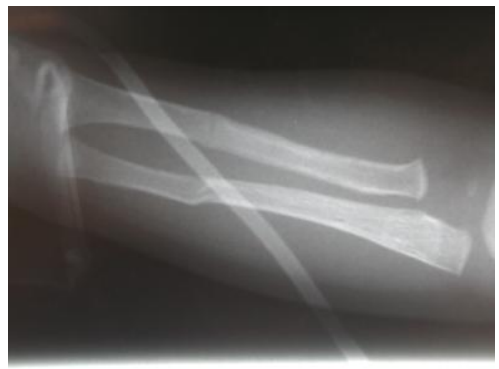

6. Others. Dislocation of the shoulder and pelvic joints (Because of pulling). Signs of repeated injury.

Imaging is a very useful way to detect disguised trauma, $80 \%$ of the disguised fractures are found in children under one year old. ${ }^{6,7,14,15}$ Fractures in children under one year of age are usually caused by improper handling. The risk for improper handling which results in fractures will be higher in children under 4 months. Femoral fractures caused by improper handling account for $92,8 \%$ in children under 1 year old. ${ }^{6,7,16}$

Surveys of complete bones should be performed in children under 2 years suspected of child abuse. ${ }^{6,7,14-16}$ The bone survey in our case revealed untreated multiple fractures with a variety of healing phases. Based on this, it was suspected that they were caused by physical abuse. 
The differential diagnoses for child abuse include osteogenesis imperfecta. Physical abuse can be differentiated from osteogenesis imperfecta by exploring the patient's history, physical and radiological examinations. The patient's and family's history assists radiologists to determine physical abuse. Differentiating osteogenesis imperfecta from physical abuse includes osteogenesis imperfecta with blue sclera, abnormal teeth, family's history of susceptibility to broken bones, hearing disorders, radiological findings such as wormian bones and osteoporosis. ${ }^{6-8}$ Metaphysical corner fractures, bucket-handle fractures and other fractures uncover physical abuse. In our case, signs of osteogenesis imperfecta were absent so that diagnosis of physical abuse could be established.

The right measures for handling child abuse include : prevention, identification, reporting and reference; investigation, management and follow-up, legal process, punishment or rehabilitation..$^{6-18}$

In Indonesia, there is a special agency now, called Lembaga Perlindungan Anak (LPA). ${ }^{2}$ This institution serves like a child protection service agency in USA. This agency can be found in almost every province. If there is a child suspected of improper treatment, the doctor will report to that agency and the staff will immediately consult to the reporting doctor to find out if the victim will be safe if still living with his / her parents or he or she needs hospitalization for injury treatment and further evaluation. Then, the parents or person suspected or being the abuser and the patient will be handled by one team to determine the shortterm as well as the long-term plans for this abusive family.

Wrong treatment contributes to death by $5 \%$ if the case is not interfered by an agency member. $25 \%$ of the victims will get repeated serious injury and can cause permanent disability, physically as well as intellectually besides emotional disorders, behavior, other psychiatric problems, ataxia, hydrocephalus, organic brain syndrome, mental retardation, as well as establishment of abused behavior. ${ }^{7,8,19,20}$

The management of suspected physical abuse in children is shown as follows $:^{2}$

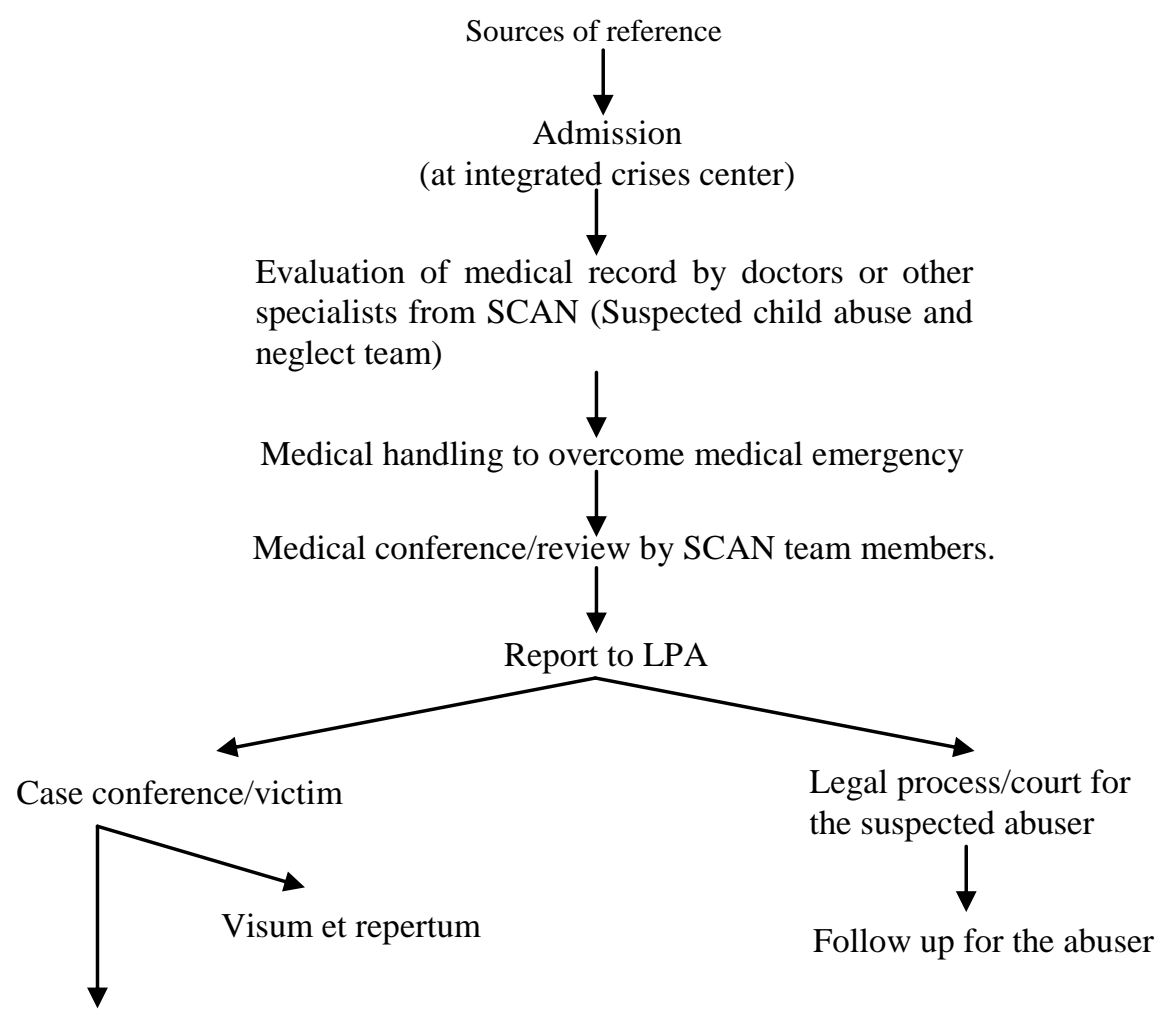

Follow up for case /victim 
There are three kinds of child-abuse prevention. The primary prevention is directed to a group which has not or does not do wrong treatment, in the form of promotion. The secondary prevention is directed to those included into the high-risk group by offering intervention. The tertiary prevention is directed to those requiring prevention of repeated wrong treatment. The intensive management succeeds in rehabilitating $80-90 \%$ of the families including management in the emergency unit. ${ }^{19-22}$

In the United States, the prevention is done by National Committee to Prevent Child Abuse. As the initial intervention, it is done to all families and newborn babies. Those families are then categorized into groups. If they are included into the high-risk group, the babies' mothers will he tutored in the hospital about how to take care of babies. After that, house visits will be done regularly by professionals and nurses, at the same time, the parents are also taught about how to be cognizant of children's growth and ways to help them to grow optimally. Initial reports of those activities state that development of child mentality will be potential to grow better in accordance with better understanding of child development. ${ }^{20}$

In the national scope, the role of law in child abuse cases has been present but the points have not been listed in the criminal bill. Assessment and review of national law by adopting the convention of children's rights must be carried out. The success of law enforcement is not only dependant on the structures of law substances but on the perception, knowledge, and the opinion as well. ${ }^{23}$

Discussion groups on children's rights and children's prosperity resulted in recommendations to socialize Convention of Children's Rights in the following ways:

- Communication, information and education. All of the articles in the Convention of Children's Rights emphasize on children's protection and children's prosperity which are informed and introduced to all professionals, leaders and key persons, non-governmental organizations, employees and the society.

- Mechanisms and management of children's protection.

- Training of the children's protection agents, services toward children especially in difficult circumstances are parts of training on children's right and should be includen in the curricula of courses, schools, and universities.

- Investigation into those children to identify and to determine each problem. Conducting strategic studies should also be highlighted. ${ }^{24}$

\section{REFERENCES}

1. DiScala C, Sege R, Li G, Reece RM. Child abuse and unintentional injuries, A 10-year retrospective. Arch Paediatr Adolesc Med 2000;154:16-22

2. Widiatmoko W, Gunardi H. Tatalaksana kasus penganiayaan dan penelantaran anak. In: Widiatmoko W, Gunardi H, editors. Panduan tatalaksana kasus penganiayaan dan penelantaran anak. Jakarta: Depkes; 2000.p.1-64

3. Monteleone JA, Brodeur AE. Identifying, interpreting, and reporting injuries. In: Monteleone JA, Brodeur AE, editors. Child maltreatment. St. Louis: GW Medical Publishing; 1999.p. 41-52

4. Soetjiningsih. Perlakuan salah pada anak (Child abuse). In: Ranuh IGN, editor. Tumbuh kembang anak. $2^{\text {nd }}$ ed. Jakarta: EGC; 1995.p. 165-76

5. Giardini AP, Jellinek MS, Konop R, Sylvester C, Steiner H, Kappelman MM, et al. Child abuse and neglect: Physical Abuse. Med J 2001;26:8-23

6. Akbarnia BA, Campbell RM. The Role of the orthopedic surgeon in child abuse. In: Morrisy RT, Weinstein SL. Lovell and Winter' $s$ Pediatric Orthopaedics. $5^{\text {th }}$ ed. Philadelphia: Lippincott Williams \& Wilkins; 2001.p. 1423-45

7. Kocher MS, Kasser JR. Orthopedic aspects of child abuse. J Am Acad Orthop Surg 2000;8:10-20

8. Johnson CF. Abuse and neglect of children. In: Nelson WE, Behrman RE, editors. Textbook of pediatrics. $15^{\text {th }}$ ed. Philadelphia: Saunders; 1996.p. 112-6

9. Oates K. Global overview of child abuse. In: Kasim MS, editor. Child abuse and neglect: Asian perspective. Proceeding of the $3^{\text {rd }}$ Asian Conference on Child Abuse and Neglect. Kuala Lumpur: UNICEF; 1993.p. 1-5

10. Hyman IA. Using research to change public policy: Reflection on 20 years of effort to eliminate corporal punishment in school. Paediatr 1996: 818-20

11. Pressel DM. Evaluation of physical abuse in children. Am Fam Phys 2001;61:3057-64

12. Belfer RA, Klein BL, Orr L. Use of the skeletal in the evaluation of child maltreatment. Am J Emerg Med 2001;19:122-4

13. Scherl SA, Miller L, Lively N, Russinoff S, Sullivan CM, Tornetta P, et al. Accidental and nonaccidental femur fractures in children. Clin Orthop 200;16:96-105

14. Karen G, David A. Emergency department evaluation and treatment of pediatric orthopedic injuries. Emerg Med Clin North Am 1999;20:896-922

15. Cramer KE. Common orthopedic problem. II. Orthopedic aspects of child abuse. Paediatr Clin North Am 1996;3:34-8

16. Sane SM, Kleinman PK, Cohen RA, Di Pietro MA, Siebert JJ, Wood BP, dkk. Diagnostic imaging of child abuse. Paediatrics 2000;105:262-4 
17. Krugman R. Physical and sexual abuse. In: Kasim MS, editor. Child abuse and neglect: Asian perspectives. Proceeding of the $3^{\text {rd }}$ Asian Conference on Child Abuse and Neglect. Kuala Lumpur: UNICEF; 1993.p. 9-16

18. Doek JE. Child abuse and the law. In: Kasim MS, editor. Child abuse and neglect: Asian perspectives. Proceeding of thr $3^{\text {rd }}$ Asian Conference on Child Abuse and Neglect. Kuala Lumpur: UNICEF; 1993.p. 154-61

19. Bethea L. Primary prevention of child abuse. Amn Fam Phys 1999;6:201-22

20. Sicher P, Lewis O, Sargent J, Chaffin M, Friedrich WN. Developing child abuse prevention, identification, and treatment systems in Eastern Europe. Am Child Adol Psycol 2000;39:36-9
21. Jain AM. Emergency department evaluation of child abuse. Emerg Med Clin North Am 1999;17:14

22. Benger JR, Pearce AV. Simple intervention to improve detection of child abuse in emergency departments. BMJ 2002;324:780-2

23. Muladi. Law and law enforcement on the rights of the child and child protection. In: Sudiyanto D, Natanagara D, editors. Proceeding of the $6^{\text {th }}$ ASEAN Paediatric Federation Conference. Denpasar: UNICEF; 1992.p. 34-6

24. Rilantono L (Moderator). Group Discussion on the Right of the Child and Child Welfare. In: Sudiyanto D, Natanagara D, editors. Proceeding of the $6^{\text {th }}$ ASEAN Paediatric Federation Conference. Denpasar: UNICEF; 1992.p. 73-5 
